DOI:

\author{
Тихонов Виталий Витальевич, \\ доктор исторических наук, ведущий научный \\ сотрудник Института российской истории РАН, \\ профессор Российского государственного \\ гуманитарного университета (г. Москва)
}

\title{
«ИНСТИТУТ ИСТОРИИ АН СССР \\ И «ДЕЛО» П.И. ЯКИРА» ${ }^{1}$
}

\begin{abstract}
Аннотация. Автор рассматривает проблему генезиса диссидентского движения в СССР на примере «дела» Петра Якира - сотрудника академического Института истории. Якир был сыном военачальника, репрессированного в сталинские годы, и сам долгое время носил клеймо «врага народа». После XX съезда КПСС семью реабилитировали, однако рамки официально дозволенной свободы обсуждения сталинизма были очень ограничены. Фигура Петра Якира, участвовавшего в неофициальной общественной жизни 1960-х гг., но «отрекшегося» от инакомыслия под угрозой нового тюремного срока, рельефно показывает противоречивость отношений профессиональной корпорации историков СССР с властью и элементами гражданского общества.
\end{abstract}

Ключевые слова: историография, советские диссиденты, шестидесятники, инакомыслие, Институт истории.

Tikhonov Vitaly Vitalievich, Doctor of History, Leading Researcher Institute of Russian History, Professor, Russian State University for the Humanities (Moscow)

\section{INSTITUTE OF HISTORY AND THE CASE OF PETR YAKIR}

Annotation. The author examines the problem of the genesis of the dissident movement in the USSR on the example of the "case" of Pyotr Yakir, an employee of the Academic Institute of History. Yakir was the son of a military

1 Лекция прочитана 30 октября 2021 г. в рамках VI Всероссийской научнопрактической конференции «Время надежд: XX съезд КПСС. Причины, последствия, нереализованные возможности». 
leader who was repressed during the Stalin years, and for a long time himself had the status of an "enemy of the people." After the 20th Congress of the CPSU, the family was rehabilitated, but the scope of the officially permitted freedom to discuss Stalinism was very limited. The personality of Pyotr Yakir, who participated in the unofficial social life of the 1960s, but "renounced" dissent under the threat of a new prison term, clearly shows the contradictions between the professional corporation of Soviet historians, the authorities and elements of civil society.

Keywords: historiography, Soviet dissidents, the sixties, dissent, Institute of History.

В героическом «диссидентском мифе» присутствует разделение на так называемых «официальных историков» и независимых историков, являвшихся частью диссидентского движения ${ }^{1}$. Причем нередко под «официальными историками» подразумевались профессиональные историки вообще. Но такое разделение выглядит чрезмерно радикальным. В реальности границы были подвижны, ряд профессиональных историков тесно соприкасался с диссидентской средой, а некоторые активные участники диссидентского движения когда-либо имели официальное место работы в научно-исследовательских институтах (братья Медведевы, П.И. Якир, М.Я. Гефтер).

Часто в качестве ответа на вопрос о мотивах дистанцирования профессиональных историков от общественной активности в советкое время отмечается страх потери карьеры или культивация аполитичности. Не отрицая и этих мотивов, можно указать, что нежелание большинства «ученой братии» (впрочем, в обсуждения на ученых советах и открытых заседаниях, по крайней мере в 1960-е гг., вовлекался не один десяток человек) участвовать в бурных дебатах отражает, скорее, уровень их общественного темперамента, а не некую демонстративную позицию. Сказывалось и отсутствие в СССР полноценного «публичного пространства». Безусловно, среди советских ученых можно выявить установку, согласно которой ученый должен в первую очередь выполнять свой профессиональный долг, а не увлекаться политикой, мешающей и ставящей под удар выполнение его прямых профессиональных обязанностей. Многие считали, что именно так можно сделать мир немного лучше (это напоминало теорию «малых дел»). 
Для осмысления указанных установок используется концепция «идеологии профессионализма». По мнению Н. Копосова, «...советская историография культивировала идеал члена сражающегося коллектива... В 1960-1970-е гг. он уступил место образу аполитичного эксперта, которому соответствовала идеология профессионализма. Отказ от теории во имя фактографии скрывал как неприятие склеротической идеологии, так и неготовность выступить против нее» ${ }^{2}$. Думаю, что нарисованная широким мазком картина сильно упрощает реальность. Можно ли назвать В.П. Данилова, А.М. Некрича, М.Я. Гефтера и их оппонентов «аполитичными экспертами» ${ }^{3}$ ? Неслучайно перечисленные историки вполне вписаны как в академическую историю науки, так и в диссидентский нарратив. А известный «даниловский партком» стал заметным явлением общественной жизни столицы, превратившись в центр притяжения сторонников демократизации и десталинизации исторической науки. Вообще, по меткому наблюдению Б. Мартин, политическая заостренность исторических текстов диссидентов была во многом следствием открытой политизированности советской историографии ${ }^{4}$. То есть аполитичность - это не тот термин, который позволяет прояснить ситуацию. Также Б. Мартин признала, что четко отделить историков-диссидентов от профессиональной среды не получается 5

Подвижность границ между частью историков (как правило, они идентифицировали себя как «историки-шестидесятники») хорошо демонстрирует судьба одного из самых известных деятелей диссидентского движения - П.И. Якира, сына расстрелянного в 1937 г. командарма И.Э. Якира. Он оказался в заключении еще в детстве и провел по лагерям и ссылкам в общей сложности 17 лет. После реабилитации сумел поступить в Историкоархивный институт, который окончил с отличием и стал, будучи уже немолодым человеком, аспирантом Института истории. Здесь он подготовил диссертацию на тему «Перевод Красной армии на мирное положение, 1921-1923 гг.», которую рекомендовали к защите (защищена так и не была). Он получает хорошие характеристики от заведующего сектором истории Революции и Гражданской войны П.Н. Соболева (человека, считавшегося сто- 
ронником ортодоксальных взглядов) и Научного совета по комплексной проблеме «История Великой Октябрьской социалистической революции» ${ }^{6}$ и с 1 января 1966 г. зачисляется в Научный совет на должность младшего научного сотрудника ${ }^{7}$. Это не могло обойтись без санкции руководителя совета - академика И.И. Минца, знавшего отца Якира.

Но в том же году Якир-младший начинает активную общественную деятельность (что, видимо, затормозило доведение диссертации до защиты). В определенном смысле этому способствовала общественная атмосфера Института истории во второй половине 1960-х гг. Устремления историков-шестидесятников (как они сами себя идентифицировали) и многих участников диссидентского движения в целом совпадали. На это время приходится активная деятельность так называемого «даниловского парткома», выступавшего за десталинизацию и демократизацию исторической науки, проходит бурное обсуждение книги А.М. Некрича «1941, 22 июня».

Во всех этих событиях Якир принимал деятельное участие, в том числе и за рамками академической среды. Он активно выступает против ресталинизации и участвует в «подписных» кампаниях. В январе 1968 г. П. Якир, Ю. Ким и И. Габай выступили с обращением «К деятелям науки, культуры, искусства», в котором выражался протест против ресталинизации и преследования инакомыслящих. Видимо, это стало последней каплей для контролирующих органов, на П. Якира началось давление на работе. Прошло по меньшей мере два собрания, на которых его деятельность подверглась осуждению. Поводом стало письмо рабочих завода «Красный пролетарий», возмущенных, якобы, антисоветской позицией «подписантов».

Доступен протокол первого собрания, проходившего 28 марта 1968 г. и собравшего сотрудников Научного совета по комплексной проблеме «История Великой Октябрьской социалистической революции», а также сотрудников других секторов и групп. Председателем являлся Г.А. Трукан, присутствовало 52 человека. Открывая собрание, председатель указал, что «на повестке... вопрос о политически безответственном поведении младшего научного сотрудника Научного совета П.И. Якира» ${ }^{8}$. Говорилось, что 
подписанные Якиром воззвания стали орудием в руках антисоветской пропаганды за рубежом (в частности, были зачитаны на «Голосе Америки»). Помимо этого, распространяя их, он нарушал производственную дисциплину.

Неожиданно выступил «старый большевик» А.П. Кучкин, предложивший выслушать обсуждаемого. Трукан раздраженно подчеркнул, что «важнее оценить действия Якира и документы, подписанные им». Далее протокол отразил следующий диалог:

«Якир: Я не знаю, о чем мне говорить.

Кучкин: Что заставило Вас подписать антигосударственное письмо, что за сообщники, что толкнуло Вас к этому. Потом будем решать, как с Вами поступать.

Якир: Мои друзья - честные советские люди и документ тоже [честный]. Меня никто никогда не толкал. Считаю, что правильно поступил, это голос совести. Писал не для "Голоса Америки”, а для советских людей. Как оно туда попало - не знаю. Подписал этот документ, так как это мой гражданский долг. Не раскаиваюсь в этом» ${ }^{9}$.

Вскоре выяснилось, что мало кто знает о содержании обращения «К деятелям науки, культуры, искусства». Трукан вновь напомнил, что обсуждается не письмо, а поведение Якира, поэтому выяснять содержание обращения не надо. Его поддержал И.И. Минц, сказавший, что письмо уже передавали по «Голосу Америки» и ВВС - 15 раз (видимо, намекал, что кому надо - тот уже мог давно ознакомиться). Но большинство участников продолжало настаивать на оглашении документа. Трукан зачитал письмо. После этого И.И. Минц выступил в том духе, что нельзя врагам Советского Союза давать повод давления на страну, а Якир именно это и сделал ${ }^{10}$. Интересно, что Минц напирал на «долг профессионализма»: историк должен заниматься своей работой, «завоевать право называться научным работником» ${ }^{11}$. Ему вторил Д.А. Коваленко: «Научным трудом надо исправлять ошибки прошлого. Вместо этого Вы помогаете заполнять эфир злобными антисоветскими измышлениями» ${ }^{12}$. В том же духе выступили В.Ф. Миллер, Б.Н. Казанцев, С.С. Хесин. А.П. Кучкин заявил, что Якир не раскаялся. В русле новых веяний он говорил: «Чем объяснить, что Якир стал на такой путь. У него произошел психологический срыв, это мы понимаем. Никто не оправдывает 
нарушение демократии периода культа Сталина, но нельзя десятки лет муссировать это и тем самым лить воду на мельницу наших врагов. Ненависть Якира к Сталину может перерасти у Вас в ненависть к советскому строю, социализму, бойтесь этого... Я что-то теряю веру в то, что он может в нашем коллективе исправиться. Не стоит ли сделать то же, что сделали в Польше с частью студентов, - послали на производство для оздоровления. Вам надо увидеть, чем дышит рабочий класс, тогда Вы поймете свою ошибку» ${ }^{13}$.

Компромиссную позицию занял М.П. Ким. Он предложил ответить на обвинения самому Якиру. Тот сказал: «Сожалею, что письмо передано по иностранному радио. 17 лет работал токарем, в шахте и в лесу. Сбор подписей не отнимает времени. С диссертацией - затянул, сейчас она на внешней рецензии. Сам хочу ускорить ее завершение, конечно, какое-то время упустил» ${ }^{14}$. Выступивший следом М.П. Ким делал упор на необходимости перевоспитании Якира в коллективе Института истории, а не увольнение его или «высылку к рабочим». Но выступавший потребовал, чтобы тот отрекся от своих «клеветнических писаний». Заявление Якира о том, что он не считает содержание письма ошибочным и «обещает подумать, может быть, и изменить мнение» вызвало шум и протесты собрания. Единогласно была принята резолюция, осуждающая поведение Якира. Пожалуй, на данном примере можно хорошо увидеть, что «идеология профессионализма» (разумеется, в усеченном виде) могла использоваться в качестве инструмента давления и контроля. Апелляция к ней позволяла вывести политику за рамки профессионального долга.

Согласно справке, представленной 29 августа 1972 г. в следственный отдел КГБ (т.е. во время следствия по делу «Якира Красина») и подписанной заместителем директора Г.А. Труканом, 10 апреля 1968 г. прошло собрание отдела истории советского общества Института (т.е. собрание секторов, входивших в отдел), на котором присутствовало 68 человек. Выступили восемь человек, включая академика И.И. Минца и члена-корреспондента М.П. Кима. На собрании вменялось и нарушение трудовой дисциплины, «недобросовестное отношение к служебным обязанностям». Якир на собрании «вел себя неискренне, а на прямой вопрос: будет ли он продолжать участвовать в составлении антисоветских воззваний и заявлений, он ответил: "Не будет, если советское правительство 
своей политикой не принудит его к этому"»"15. Собрание приняло резолюцию, в которой осудило деятельность Якира и отметило «несовместимость этих действий с дальнейшим пребыванием в идеологическом учреждении» ${ }^{16}$.

После разделения Института истории на Институт истории СССР и Институт всеобщей истории ${ }^{17}$ Якир был уволен и переведен на должность библиографа в ИНИОН. В эти годы он становится одним из лидеров диссидентского движения. В 1972 г. его и В. Красина арестовали и после давления оба публично покаялись, что произвело тяжелое впечатление в диссидентских кругах. Близко знавший Якира сотрудник Института А.П. Ненароков вспоминает, что во время посещения Якира в рязанской ссылке тот сказал ему: «Ну не мог я еще раз сидеть, ни месяца, ни недели. Когда объявляли приговор, несмотря на все уверения, что его заменят [на более мягкий], меня трясло» ${ }^{18}$. После освобождения П.И. Якир уже не принимал деятельного участия в диссидентском движении. Он часто приходил в Институт истории, где продолжали работать многие его друзья и знакомые. По воспоминаниям свидетелей, Якир производил впечатление сломленного человека. Скончался он в 1982 г.

Случай Якира демонстрирует, что в 1960-е гг. сообщество диссидентов и круги профессиональных историков находились в более или менее тесном взаимодействии. Якир стремился сделать карьеру профессионального историка, но общественный темперамент взял верх. Впрочем, рост общественной активности в самом Институте истории также создавал соответствующую атмосферу. Тем не менее среди значительной группы историков сохранялась ограничивающая трактовка «идеологии профессионализма», в которой долг историка состоял в выполнении профессиональной работы. Впрочем, можно предположить, что в значительной мере перед нами риторический прием, используемый стремящимися осудить деятельность Якира. Усиление контроля, притеснения ряда историков-шестидесятников, разгром так называемого «нового направления» (историки, стремившиеся по-новому переосмыслить предпосылки Октябрьской революции) и т.д. привели к тому, что академическая среда рассматривалась как все более догматичная. Историки-диссиденты 1970-х гг. уже демонстративно дистанциро- 
вались от «официальных» историков, не ища контактов с ними. Процесс Якира - Красина подвел черту под первым этапом диссидентского движения.

${ }^{1}$ Например: Исторический сборник «Память»: исследования и материалы / сост., комм. Б. Мартин, А. Свешников. М.: НЛО, 2017. С. 212, 245, 342 и др.

${ }^{2}$ Копосов Н. Память строгого режима: история и политика России. М.: НЛО, 2011. С. 192. Об этом же писал В. Шлапентох в отношении ученых в целом: Shlapentokh V. Soviet Intellectuals and Political Power. Princeton: Princeton University Press, 1990. P. 93-98. Позиция Н.Е. Копосова была поддержана А.В. Свешниковым, см.: Исторический сборник «Память». С. 165.

${ }^{3}$ Партийная организация Института истории АН СССР в идейном противостоянии с партийными инстанциями / публ. Л. В. Даниловой // Вопросы истории. 2007. № 12; 2008. № 1-2; Martin B. Dissident histories in the Soviet Union: From De-Stalinization to Perestroika. London: Bloomsbury Academic, 2019. P. 75-81.

${ }^{4}$ Исторический сборник «Память». С. 50.

${ }^{5}$ Martin B. Op.cit. P. 110.

${ }^{6}$ НА ИРИ РАН. Ф. 1. Личное дело П.И. Якира. Л. 17-18.

${ }^{7}$ Там же. Л. 27.

${ }^{8}$ Там же. Л. 21.

${ }^{9}$ Там же. Л. 22.

${ }^{10}$ По воспоминаниям А.П. Ненарокова И.И. Минц держал Якира в Научном совете столько, сколько позволяли обстоятельства, см.: Ненароков А.П. В поисках жанра. Записки архивиста с документами, комментариями, фотографиями и посвящениями. Кн. 1. Вдаль к началу. М.: Новый хронограф, 2009. С. 235.

${ }^{11}$ НА ИРИ РАН. Ф. 1. Личное дело П.И. Якира. Л. 23.

${ }^{12}$ Там же.

${ }^{13}$ Там же. Л. 24-25.

${ }^{14}$ Там же. Л. 25.

${ }^{15}$ Там же. Л. 19.

${ }^{16}$ Там же. Л. 20.

${ }^{17}$ Часто разделение Института связывают именно со стремлением уволить П.И. Якира. Скорее всего, это не так, причин было немало, и доминировали общеорганизационные соображения. См.: Пивоваров Н.Ю., Тихонов В.В. «Штатов изобилье, порядка снова нет»: к истории разделения Института истории АН СССР в 1968 г. // Российская история. 2020. № 3. С. 173-184.

${ }^{18}$ Ненароков А.П. Указ. соч. С. 236. 